\title{
STUDY OF MORPHOLOGICAL CHARACTERS OF TRANSPLANTED TREES WITH SPECIAL REFERENCE TO THEIR MEDICINAL IMPORTANCE
}

\author{
ANANT PRAKASH ${ }^{1}$ \\ Department of Botany, Ch.Charan Singh Degree College, Heonra, Etawah, U.P., India
}

\begin{abstract}
Morphological study of transplanted tree is the foundation of this investigation. This research work is focused on documentation of transplanted tree on the basis of their morphological character and economic value with special reference to its medicinal value, there are thirteen trees described on the basis of their morphological characters, Azadirachta indica, Bauhinia variegata, Pongamia pinnata, Jacaranda mimosifolia, Dalbergia sissoo, Dalbergia latifolia, Mimusops elengi, Ficus virens, Ficus bengalensis, Ficus religiosa, Bombax malabaricum, Kigelia Africana, Tabebuia sp. All morphological characters are based on the taxonomic features of leaf. They are used in fodder, timber, oil, beverages, and ornamental purposes.On the basis of these characteristics trees can be easily identified and utilized in various purposes, which is baseline for the forest field and useful to upliftment of forest economy by proper utilization of tree parts.
\end{abstract}

KEYWORDS: Morphological, Transplantedtree, Medicianal

Forest is an important component of our environment and economy. Forests also have aesthetic, recreational and tourist value and serve as gene reserve of important species. Leaves also play key role in plant functioning and long term adaptation to the environment.

According to Marcos Melocorea (2015), morphological studies focusing on vegetative traits are useful in identifying species when fertile materials are not available. This study assesses the application of comparative leaf morphology to identify species of the transplanted trees (www.scielo.br>scielo). Tree morphology incorporates architectural, biomechanical and physiological aspects of the tree as well as areas in science and mathematics such as fractals conducive to computer modeling to enhance understanding of tree growth.

To my knowledge, this is the first morphological study of transplanted tree of Fisher forest and Lion Safari. Leaf morphology explores the identification, economic importance of trees with special reference to their medicinal values. Plant morphology is useful in visual identification of plant. Mathur (1988) described that the formulation of the principles of taxonomy began with the period of descriptive taxonomy which had its main period of development on a scientific level in the $19^{\text {th }}$ century. This was mainly concerned with the observation of the similarities and the differences in the gross morphological characters of the plants discovered at that time all over the surface of the earth. This descriptive taxonomy began with the works of Tournfort, de Jussieu and Linnaeus and followed by Robert Brown, Hookers, John Lindley, George Bentham, de Candolles and several others. The plants were described and classified according to the morphological characters. The present day taxonomy is based primarily on the morphological characters and affinity. According to Shukla and Misra (1992) major classification available now are those which based on morphology.

The current research was conducted with this background. The objective of this work is to identify the trees on the basis of their morphological characters and their economic values. Hopefully this study will provide useful information for identification of transplanted tree, and its economic utilization, with special reference to its medicinal value.

\section{MATERIALS AND METHODS}

Taxonomical Characters of Various Tree Species and Economic Importance of Plants

Various transplanted plant twigs are collected from the Fisher forest and Lion Safari and identified in the laboratory with the help of flora of Uttar Pradesh (Singh et al., 2016) and their economic importance was also studied. Mature leaves were collected from the top of the stem from trees transplanted before 4 years and studied in the laboratory with help of various reference books like Duthie flora, Chavan and mathur, Exotic tree internet and Botanical review and Gazeets of Kolkata, Interested flowering trees. 
PRAKASH: STUDY OF MORPHOLOGICAL CHARACTERS OF TRANSPLANTED TREES WITH...

\section{Research Site}

Fisher forest, Etawah lies in the western part of U.P. at $26^{\circ} 47^{\prime \prime}$ north latitude and $72^{0} 20^{\prime \prime}$ east longitude. The pioneer work for the protection of land from erosion by establishing the forest was initiated by Mr. Fisher (Collector of Etawah) in 1888. Therefore, this forest is called Fisher forest. Lion Safari is about $25 \mathrm{~km}$ from Research Centre Heonra, Etawah, $109 \mathrm{~km}$ from Gwalior and $120 \mathrm{~km}$ from Agra.

\section{Study of Morphological Characters of Transplanted Tree}

In Fisher forest and Lion Safari transplanted trees were 3-4 years old only. Therefore leaf morphological feature are described only. This is sufficient for identification for plant. (Table 1)

\section{Azadirachta indica}

A. Juss: Leaves pari-or imparipinnate, $10-45 \mathrm{~cm}$ long,leaflet 9-18,opposite or alternate,ovate-lanceolate,4$9 * 1-2.3 \mathrm{~cm}$,acuminate at apex,prominently oblique at base, coarsely crenate-seirate, along margins,glabrous terminal leaflet after aborted;petiolutes 2-3mm long.

\section{Bombax malabaricum D.C.}

Leaves slightly broader than long $5-15 \mathrm{~cm}$ long, divided 1/3 way down Cordate at base 9-15 nerved; lobes obtuse.

\section{Dalbergia latifolia Roxb}

Leaves impair-pinnate, alternate $10-15 \mathrm{~cm}$ long leaflets 5-7, equal in size,broadly elliptic.Obovate or subordicular, $3.5-6.5 \mathrm{~cm}$ long and broad,obtuse or emarginated at apex,cuneate at base glabrous.

\section{Dulbergia sissooD.C}

Leaves imparipinnate, 10-20 cm long, leaflets 35 , alternate broadly ovate or subordicular,2.5-6*2.5-4 $\mathrm{cm}$,cupidate or acuminate at apex, appressed pubescent at first beneath,glabrous when old.

\section{Ficus bengalensis $\mathbf{L}$.}

Leaves 4-8 inch long 2-5 inch broad, egg shaped, rounded or elliptical tip blunt, base rounded or somewhat heart shaped, 3 to 7 nerves arising from the base.

\section{Ficus religiosa $\mathbf{L}$.}

Leaves leathery, 4 to 8 inch long by 3 to 5 inch wide, somewhat egg shaped or rounded tailed at the tip and heart shaped at the base, or sometimes rounded.

\section{Ficus virens Dryander}

Leaves are $8-19 \mathrm{~cm}$ long and 3-6 $\mathrm{cm}$ wide,with a whitish midrib stipules are less than $1 \mathrm{~cm}$ long,ovate lanceolate in shape leaves thin,shining green above,duller paler green below, leaves with a short tip.

\section{Jacranda mimosifolia}

Leaves are borne at the ends of branches bipinnately compound,symmetrical like a fern,entire obovate,rhomboid,leaf blade less than 2 inches.

\section{Kigella Africana (Lans.) Benth}

Leaves opposite, leathery elliptic to ovate ablong, upto $10 \mathrm{~cm}$ long entire strigose beneath.

(https://sites.google.com>bignoniaceae)

\section{Pongamia pinnata (L.) pierre}

The imparipinnate leaves of the tree alternate and are short- stalked, rounded or cuneate at the base, ovate or oblong along the length, obtuse-acuminate at the apex and not toothed on the edges. They are a soft, shiny burg undy when young and mature to a glossy deep green as the season progress with prominent veins underneath.

\section{Mimusopa elengi L.}

Leaves are glossy, dark green, elliptic, short or long acuminate $5-14 \mathrm{~cm}$ (2-5.5 inch) long and 2.5-6 cm (0.98-2.36 inch) wide closely but faintly veined.

\section{Tabebuia argentea}

Compound leaf, 5 leaves present, middle leaf large, lower side leaves are small, leaf size $12 \mathrm{~cm}$ large and $7 \mathrm{~cm}$ wide. 
PRAKASH: STUDY OF MORPHOLOGICAL CHARACTERS OF TRANSPLANTED TREES WITH...

Table 1: Leaf Based Morphological Studied of Various Tree Species

\begin{tabular}{|c|c|c|}
\hline S.No & Botanical Name & Characteristic Features of leaf \\
\hline 1 & $\begin{array}{l}\text { Azadirachta indica } A \text {. } \\
\text { Juss }\end{array}$ & $\begin{array}{l}\text { Leaves pari-or impari-pinnate, } 10-45 \mathrm{~cm} \text { long; leaflets } 9-18 \text {, opposite or alternate, ovate- } \\
\text { lanceolate, } 4-9 \times 1-2.3 \mathrm{~cm} \text {, acuminate at apex, prominently oblique at base, coarsely crenate- } \\
\text { serrate, along margins, glabrous, terminal leaflet often aborted; petiolules } 2-3 \mathrm{~mm} \text { long. }\end{array}$ \\
\hline 2 & $\begin{array}{l}\text { Bombax } \\
\text { malabaricum DC }\end{array}$ & $\begin{array}{l}\text { Leaves digitate } 5,7 \text { foliolate, leaflets lanceolate or elliptic, } 8-18 \times 5.8 \mathrm{~cm} \text { acuminate at apex, } \\
\text { tapering at base, entire, glabrous, petioles, } 12-20 \mathrm{~cm} \text { long; stipules triangular. }\end{array}$ \\
\hline 3 & $\begin{array}{l}\text { Bauhinia variegata } \\
\text { L. }\end{array}$ & $\begin{array}{l}\text { Leaves slightly broader than long, } 5-15 \mathrm{~cm} \text { long, divided } 1 / 3 \text { way down cordate at base } 9-15 \\
\text { nerved; lobes obtuse. }\end{array}$ \\
\hline 4 & $\begin{array}{l}\text { Dalbergia latifolia } \\
\text { Roxb. }\end{array}$ & $\begin{array}{l}\text { Leaves impair -pinnate, alternate } 10-15 \mathrm{~cm} \text { long leaflets } 5-7 \text {, nequal in size, broadly } \\
\text { elliptic. obovate or suborbicular, } 3.5-6.5 \mathrm{~cm} \text { long and broad, obtuse or emarginate at apex, } \\
\text { cuneate at base, glabrous. }\end{array}$ \\
\hline 5 & Dalbergia sisoo D.C. & $\begin{array}{l}\text { Leaves imparipinnate, } 10-20 \mathrm{~cm} \text { long, leaflets } 3-5 \text {, alternate broadly ovate or Suborbicular, } \\
2.5-6 \times 2.5-4 \mathrm{~cm} \text {, cuspidate or acuminate at apex, appressed pubescent at first beneath, } \\
\text { glabrous when old. }\end{array}$ \\
\hline 6 & Ficus bengalensis L. & $\begin{array}{l}\text { Leaves 4-8 inch long 2-5 inch broad, egg -shaped, rounded or elliptical tip blunt, base } \\
\text { rounded or somewhat heart shaped, } 3 \text { to } 7 \text { nerves arising from the base. }\end{array}$ \\
\hline 7 & Ficus religiosa L. & $\begin{array}{l}\text { Leaves leathery, } 4 \text { to } 8 \text { inch long by } 3 \text { to } 5 \text { inch wide, somewhat egg shaped or rounded, } \\
\text { tailed at the tip and heart shaped at the base, or some times rounded. }\end{array}$ \\
\hline 8 & $\begin{array}{l}\text { Ficus } \\
\text { Dryander }\end{array}$ & $\begin{array}{l}\text { Leaves are } 8-19 \mathrm{~cm} \text { long and } 3-6 \mathrm{~cm} \text { wide, with a whitish midrib stipules are less than } 1 \mathrm{~cm} \\
\text { long ovate lanceo-late in shape leaves thin, shing green above, duller paler green below, } \\
\text { leaves with a short tip. }\end{array}$ \\
\hline 9 & Jacranda mimosifolia & $\begin{array}{l}\text { Leaves are borne at the ends of branches bipinnately,compound, symmetrical like a fern. } \\
\text { entire obovate, rhomboid, leaf blade less than } 2 \text { inches }\end{array}$ \\
\hline 10 & $\begin{array}{l}\text { Kigella africana } \\
\text { (Lans) Benth }\end{array}$ & $\begin{array}{l}\text { Leaves Opposite, Pinnate compound, leaflet 5-9 leathery, elliptic to ovate-oblong, upto } \\
10 \mathrm{~cm} \text { long, } 6-8 \mathrm{~cm} \text { broad, }\end{array}$ \\
\hline 11 & $\begin{array}{l}\text { Pongamia pinnata } \\
\text { (L.) Pierre }\end{array}$ & $\begin{array}{l}\text { Leaves imparipinnate, } 7-25 \mathrm{~cm} \text { long, leaflets } 5-7 \text {, ovate or oblong } 5-10 \times 5-8 \mathrm{~cm} \text {, acute or } \\
\text { acuminate at apex obtuse at base; petioles } 5-6 \mathrm{~cm} \text { long }\end{array}$ \\
\hline 12 & Mimusopa elengi $\mathrm{L}$ & $\begin{array}{l}\text { Leaves are glossy, dark green, elliptic, short or long acuminate } 5-14 \mathrm{~cm}(2-5.5 \text { inch) Long } \\
\text { and } 2.5-6 \mathrm{~cm}(0.98-2.36 \mathrm{inch}) \text { wide closely but faintly veined. }\end{array}$ \\
\hline 13 & Tabebuia argentea & $\begin{array}{l}\text { From } 5 \text { to } 7 \text { oglong silvery grey, oblong leaflets, roughly } 4 \text { inches wide and } 11 \text { inches long. } \\
\text { Fan outward like the extended fingers of a hand botanists call palmate. }\end{array}$ \\
\hline
\end{tabular}

Table 2: Key Characters of Leaf

\begin{tabular}{|c|l|l|l|c|}
\hline Sl. No. & \multicolumn{1}{|c|}{ Botanical Name } & \multicolumn{1}{c|}{$\begin{array}{c}\text { Common } \\
\text { Name }\end{array}$} & \multicolumn{1}{|c|}{ Key Character } & Reference \\
\hline 1. & Azadirachta indica A.Juss & Neem & $\begin{array}{l}\text { Leaflet opposite or } \\
\text { alternate ovate, lanceolate }\end{array}$ & K.P. Singh \& G.P. Sinha (2016) \\
\hline 2. & Bombax malabaricum DC & Semal & Leaves digitate & Khanna (2016) \& Mishra (1988) \\
\hline 3. & Bauhinia variegata L. & Kachnar & Leaves cordate & Shukla (2016), Mishra (1988) \\
\hline 4. & Dalbergia latifolia Roxb. & Kala Shisham & Leaflet elliptic obovate & Shukla \& Singh (2016) \\
\hline 5. & Dalbergia sisoo DC & Shisham & Leaflet ovate & $\begin{array}{c}\text { B.K. Shukla \& A.N. Singh (2016) } \\
\text { D.N. Mishra (1988) }\end{array}$ \\
\hline 6. & Ficus bengalensis L. & Bargad & Leaf broad rounded & $\begin{array}{c}\text { R.K. Chakravirty \& S.K. Jain, } \\
\text { D.N. Mishra (1988) }\end{array}$ \\
\hline 7 & Ficus religiosa L. & Pipal & $\begin{array}{l}\text { Leaf heart shaped, } \\
\text { tailed at the tip }\end{array}$ & $\begin{array}{c}\text { R.K. Chakravirty \& S.K. Jain, } \\
\text { D.N. Mishra (1988) }\end{array}$ \\
\hline
\end{tabular}


PRAKASH: STUDY OF MORPHOLOGICAL CHARACTERS OF TRANSPLANTED TREES WITH...

\begin{tabular}{|c|l|l|l|c|}
\hline 8 & Ficus viren Dryander & Pakad & $\begin{array}{l}\text { Leaf whitish midrib long } \\
\text { lanceolate }\end{array}$ & www.flowersofindia. \\
\hline 9 & $\begin{array}{l}\text { Kigella africana } \text { (Lans.) Ben } \\
\text { th }\end{array}$ & Balamkhira & Leaf binately, compound & $\begin{array}{c}\text { Jacmina.pdf Flora of Up BSI } \\
\text { Singh, Khanna, Sinha }\end{array}$ \\
\hline 10 & Pongamia pinnata (L.) pierre & Kanja & Elliptic, odd pinnately & Gilman \& Watson (1994) \\
\hline 11 & Mimusopa elengi L. & Maulsiri & $\begin{array}{l}\text { Leaves are glossy dark } \\
\text { green elliptic }\end{array}$ & Shodhganga \\
\hline 12 & Tabebuia sp. & Tabebuia & $\begin{array}{l}\text { Usually palmately 3 to7 } \\
\text { foliate }\end{array}$ & Wikipeadia \\
\hline
\end{tabular}

\section{Economic Importance of Plants}

Transplanted trees have several economic values. Economic importance of various species is given below

\section{Azadirachta indica}

This is a large tree usually found in the upper gangetic plains of our country. The neem oil is extracted from the pulp of the fruits, which is used in the manufacture of margosa soap and several skin ointments. The oil cake obtained from the seeds is used as a fertilizer and manure. Almost all the parts of tree are of medicinal valve. The leaves are placed in the suitcase to repel insects and to preserve woolens. Decoction of leaves is antiseptic and used to wash ulcers and wounds. An extract of the leaves is used in the manufacture of toothpaste and soaps. The seed oil is used as an antiseptic. This oil is also burnt in the earthen lamps. Dry flower are used as a tonic. The bark is used as an antiseptic. The young branches are used as dataum. The gum, bark, leaves and seeds are used in snake bite. The wood makes a good timber. The branches are burnt as fuel. In summers people take shelter under the shade of neem tree. (Pandey, 1985)

\section{Bauhinia variegate}

Fibres obtained from the stem.Stem,bark,flowers dried bud are used in obesity, diabetes, controls, metabolism, skindisease, ulcer, worms, Athma, piles, dysentery, diarrhea, goiter.

\section{Bombax malabaricum DC}

Stem and seeds are used in oil and fibers. Bark paste on boils and blisters, stem prickles in asthma, fruits in dysentery seed paste in small pox, boils, Root extract in diarrhoea, spermatorrhoea and powder as a tonic for impotency.

\section{Dalbergia latifolia Roxb. (Kala shisham)}

A large deciduous or nearly evergreen tree with cylindrical, fairly straight stem and full rounded crown, found in the sub Himalayan tract. Indian rosewood ranks among the finest wood for furniture and cabinet work. It is valuable decorative wood suitable for carving and ornamental plyboards and veeners. It is especially useful for pattern making, calico printing blocks, mathematical instruments and screws. It is also used for gun carriage wheels, ammunition boxes and army wagons, pulleys, handles, shelves, decorative carriage parts, temple chariots, boat knees, agricultural implements, combs, razorhandles and brush backs. Carefully selected manufactured Indian rosewoodplyboards satisfy aircraft specifications. (Pandey, 1985).

\section{Dalbergia sissoo}

It occurs throughout the sub-Himalayan tract from Ravi to Assam. It is extensively cultivated in Punjab, Uttar Pradesh, Bengal and Assam. Shisham is used as high class furniture and cabinet wood widely used throughtout north India. On account of its great strength elasticity and durability, it is highly valued as constructional and general utility timber and is used for all the purposes. It is esteemed for musical instrument, charpai legs, hammer handles, shoe heels, hookah tubes and tobacco pipes. Carefully selected and manufactured plywood logs satisfy the specifications prescribed for aircraft and for this purpose, the wood from trees, growing on canal banks and in plantations is considered to be the best. (Pandey, 1985)

\section{Ficus bengalensis L.}

Leaves are used as a fodder. Plant buds, roots and latex used in diarrhea, dysentery, stops vommting, toothache, genital diseases, cough, diabetes and polyuria. (Brahmavarchaysha, 2003) 


\section{Ficus religiosa $\mathrm{L}$.}

Leaves are used as a fodder. Bark shoot,leaves and fruit used in ulcer, skin disease, antibacterial, antihelmatic Gonorrhoea, Antifungal, seeds if taken three days during mensuration, sterilizes women for long time.

\section{Ficus virens Dryander}

Leaves are used as a fodder. Bark root fibers, leaves, seeds, latex are used in Ulcer, vomiting, vaginal complains, fever, inflammation, leprosy, useful in piles, nose-diseases, gonorrhea, dysentery, inflammation of liver.

Kigella Africana (Lans.) Benth.

Fruit and seed are used in Beverages drink and leaf is used in fodder. Fruit pulp is used in Leprosy, syphilis, skin cancer, dysentery, ringworm, malaria, diabetes, pneumonia, solar keratosis, Kaposi's sarcoma, HIV related skin ailment, antioxidant, anti-inflammatory, antibacterial.

Pongamia pinnata L.(pierre)

Fruit, seed and leaf are used in fibers, oil and fodder purposes. Seed, bark and leaves are also used in Skin disease impurity of blood, leprosy, piles, leucoderma, ringworn, flatulence, diarrheoa, indigestion, antibacterial, scabies, herpes, diabetes.

\section{Mimusopa elengi L.}

Flowers are used in Perfume\&oil. Bark, leaves flowers fruits and seeds are used in Headache, skeletol fracture, cough, leucoderma, worms, spermicidal, pyorrhea, diaarrhoea, dysentery, ulcerated throat.

\section{Tabebuia}

Tabebuia stems are used in Timber. Bark and leaves have the properties of Antibacterial, antifungal, antiviral, antiparasitic, anticancer,

\section{Jacaranda mimosifolia}

Jakranda stems are used in timber. Bark, leaves and roots are used in Skin problems, venereal diseases leishmaniasis, colds, rheumatism. Antioxidant, anti depressant, antimicrobial, anticancer, antiprotozoal, hypotensive.

Economic value of plant mainly studied on two heads:
(a) Medicinal
(b) Commercial

In medicinal point of view, described the plant parts and its active component, used in cure of disease.

Table 3: Medicinal Values of Plants

\begin{tabular}{|c|c|c|c|c|}
\hline $\begin{array}{l}\text { Sl. } \\
\text { No. }\end{array}$ & $\begin{array}{c}\text { Botanical } \\
\text { Name }\end{array}$ & Active Component & Parts used & used in disease \\
\hline 1- & $\begin{array}{l}\text { Azadirachta } \\
\text { indica A. Juss }\end{array}$ & $\begin{array}{l}\text { Margoin, Nimbadin, } \\
\text { Nimban, Nulphur, } \\
\text { Essential oil, Resin, Glycosides, } \\
\text { Fattyacids, Gum, Free amino acids, } \\
\text { Starch Sugars, Quercetin, Beta-Sito } \\
\text { Sterol }\end{array}$ & $\begin{array}{l}\text { Root } \\
\text { bark,Stem } \\
\text { bark, Leaves, } \\
\text { Flowers, } \\
\text { Fruits, }\end{array}$ & $\begin{array}{l}\text { Bark used in Rhinitis affection, } \\
\text { Hypoglycaemic, Rheumatism, } \\
\text { Antipyretic, Analgesic, malarial fever, } \\
\text { Sedative, Antiulcer, anti bacterial. } \\
\text { Leaves useful in Eczema, Ringworm, } \\
\text { Fungal affection, Antiseptic, wound } \\
\text { healer, Antihelmentic, Liver stimulant, } \\
\text { Anti-leprotic whole plant useful in } \\
\text { scabies ulcer, leucoderma, Blood } \\
\text { purification, oil used in Leprosy. }\end{array}$ \\
\hline $2-$ & $\begin{array}{l}\text { Bombax } \\
\text { malabaricum } \\
\text { DC }\end{array}$ & $\begin{array}{l}\text { Naphthol, Napthaquinones, } \\
\text { Polysaccharides, } \\
\text { Anthocyanins, Shamimin \& Lupeol }\end{array}$ & $\begin{array}{l}\text { Bark, Stem, } \\
\text { Fruit, seed, } \\
\text { root }\end{array}$ & $\begin{array}{l}\text { Bark paste on boils and blisters, stem } \\
\text { prickles in asthma, fruits in dysentery } \\
\text { seed paste in small pox, boils, Root } \\
\text { extract in diarrhoea, spermatorrhoea \& } \\
\text { powder as a tonic for impotency. }\end{array}$ \\
\hline 3- & $\begin{array}{l}\text { Bauhinia } \\
\text { variegata } \mathrm{L} .\end{array}$ & $\begin{array}{l}\text { Sugar and Tannins, Hentria contane, } \\
\text { Octacosanol, Beta-sitosterol, Stigma } \\
\text { sterol, Flavonoid, Myrcetol, } \\
\text { Glycoside, kaempferol glycoside. }\end{array}$ & $\begin{array}{l}\text { Stem, bark, } \\
\text { flowers dried } \\
\text { bud }\end{array}$ & $\begin{array}{l}\text { Obesity, diabetes, controls metabolism, } \\
\text { skin disease, Ulcer, intestinal worms, } \\
\text { Asthma, Piles, dysentery, diarrhea, } \\
\text { goiter. }\end{array}$ \\
\hline
\end{tabular}


PRAKASH: STUDY OF MORPHOLOGICAL CHARACTERS OF TRANSPLANTED TREES WITH...

\begin{tabular}{|c|c|c|c|c|}
\hline $4-$ & $\begin{array}{l}\text { Dalbergia } \\
\text { latifolia } \\
\text { Roxb. }\end{array}$ & $\begin{array}{l}\text { Dalbinol, sisafolin, coumarin, } \beta- \\
\text { sitosterol, dalbergichromene lupeol, } \\
\text { latifolin and dalbergin, latinone, neo } \\
\text { flavonoid dalcriodon and Latinone, } \\
\text { tannin. }\end{array}$ & Stem bark & Leprosy, obesity worm, antioxidant. \\
\hline $5-$ & $\begin{array}{l}\text { Dalbergia } \\
\text { sissoo DC }\end{array}$ & 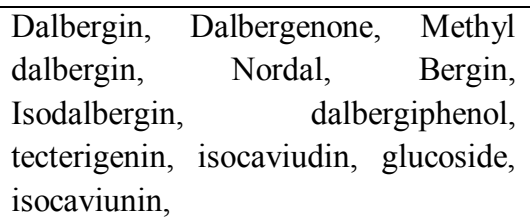 & $\begin{array}{l}\text { Leaf, wood } \\
\text { and bark. }\end{array}$ & $\begin{array}{l}\text { Leprosy, leucoderma, antipyretic, } \\
\text { appetizer, urinarydisease, dyscrosia, } \\
\text { ulcer, worms, bleeding piles, diarrhoea. }\end{array}$ \\
\hline 6- & $\begin{array}{l}\text { Ficus } \\
\text { bengalensis L. }\end{array}$ & $\begin{array}{l}\text { Glucoside, Bengalenoside, } \\
\text { Talbutamide, leucoantho cyanidins, } \\
\text { phytosterolin, Beta-sitosterol, } \\
\text { Freidelin, Quercetin, glalactoside, } \\
\text { Ticlic acid, Tannin. }\end{array}$ & $\begin{array}{l}\text { Whole plants } \\
\text { buds, roots } \\
\text { and latex. }\end{array}$ & $\begin{array}{l}\text { Diarrhoea, dysentery, stops vomiting, } \\
\text { toothache, genital diseases, cough, } \\
\text { diabetes and polyuria. }\end{array}$ \\
\hline 7- & $\begin{array}{l}\text { Ficus religiosa } \\
\text { L. }\end{array}$ & Tannin & $\begin{array}{l}\text { Bark, shoot, } \\
\text { leaves, fruit. }\end{array}$ & $\begin{array}{l}\text { Ulcer, skin disease, antibacterial, } \\
\text { Anthelmentic, Gonorrhoea, Antifungal, } \\
\text { seeds if taken three days during } \\
\text { menstruation, sterilizes women for long } \\
\text { time. }\end{array}$ \\
\hline $8-$ & $\begin{array}{l}\text { Ficus virens } \\
\text { Dryander }\end{array}$ & $\begin{array}{l}\text { Alkaloids, phenolics, flavonoids, } \\
\text { tannin }\end{array}$ & $\begin{array}{l}\text { Bark, root, } \\
\text { fibers, } \\
\text { leaves, seeds, } \\
\text { latex. }\end{array}$ & $\begin{array}{l}\text { Ulcer, vomiting, vaginal complains, } \\
\text { fever, inflammation, leprosy, useful in } \\
\text { piles, nose-diseases, gonorrhea, } \\
\text { dysentery, inflammation of liver. }\end{array}$ \\
\hline 9- & $\begin{array}{l}\text { Jacaranda } \\
\text { mimosifolia }\end{array}$ & $\begin{array}{l}\text { Flavonoids, phenyl propanoids, } \\
\text { phenyl ethanoids, sterols, triterpenes. }\end{array}$ & $\begin{array}{l}\text { Bark, leaf } \\
\text { and roots. }\end{array}$ & $\begin{array}{l}\text { Skin problems, venereal diseases } \\
\text { leishmaniasis, } \\
\text { rheumatism.Antioxidant, colds, } \\
\text { depressant, antimicrobial, anticancer, } \\
\text { antiprotozoal, hypotensive }\end{array}$ \\
\hline $10-$ & $\begin{array}{l}\text { Kigelia } \\
\text { africana(Lans.) } \\
\text { Benth. }\end{array}$ & $\begin{array}{l}\text { Norviburtinal coumarins, iridoids, } \\
\text { flavonoids, fattyacids, sterols, } \\
\text { glycosides, naptha quinines. }\end{array}$ & Fruit pulp. & $\begin{array}{l}\text { Leprosy, syphilis, skin cancer, } \\
\text { dysentery, ringworm, malaria, diabetes, } \\
\text { pneumonia, solar keratosis, Kaposi's } \\
\text { sarcoma, HIV related skin } \\
\text { ailment,antioxidant, anti-inflammatory, } \\
\text { antibacterial. }\end{array}$ \\
\hline $11-$ & $\begin{array}{l}\text { Pongamia } \\
\text { pinnata }(\mathrm{L} .) \\
\text { Pierre }\end{array}$ & $\begin{array}{l}\text { Bitter fattyoil, Pongamol, Protein, } \\
\text { Alkaloids, Tannin, Sugar, Resin, } \\
\text { Karanjin }\end{array}$ & $\begin{array}{l}\text { Seeds, bark, } \\
\text { leaves }\end{array}$ & $\begin{array}{l}\text { Skin disease impurity of blood, leprosy, } \\
\text { piles, leucoderma, ringworn, flatulence, } \\
\text { diarrhea, indigestion, antibacterial, } \\
\text { scabies, herpes, diabetes. }\end{array}$ \\
\hline $12-$ & $\begin{array}{l}\text { Mimusops } \\
\text { elengi } \mathrm{L} \text {. }\end{array}$ & $\begin{array}{l}\text { Lupeol, xylose, myrcetin, quercetin, } \\
\text { glucosides, quercitol, ursolic acid } \\
\text { glucose, triterpene, alcohol, palmitic } \\
\text { acid, stearic acid, behenic acid, oleic } \\
\text { acid, linoliec acid, lauric acid, } \\
\text { myristic acid, saponin. }\end{array}$ & $\begin{array}{l}\text { Bark, leaves, } \\
\text { flowers, } \\
\text { fruits, seeds }\end{array}$ & $\begin{array}{l}\text { Headache, skeletol fracture, cough, } \\
\text { leucoderma, worms, spermicidal, } \\
\text { pyorrhea, diaarrhoea, dysentery, } \\
\text { ulcerated throat }\end{array}$ \\
\hline $13-$ & Tabebuia sp. & $\begin{array}{l}\text { Napthoquinones,Lapachol, quinoids, } \\
\text { flavonoids, } \beta \text {-lapachone }\end{array}$ & $\begin{array}{l}\text { Bark } \\
\text { leaf. }\end{array}$ & $\begin{array}{l}\text { Antibacterial, antifungal, antiviral, } \\
\text { antiparasitic, anticancer, }\end{array}$ \\
\hline
\end{tabular}


PRAKASH: STUDY OF MORPHOLOGICAL CHARACTERS OF TRANSPLANTED TREES WITH...

In commercial point of view, described the plant beverages and drinks etc.

parts used as timber, oil, fodder, perfume, fibres and floss,

Table 4: Other Economic Value of Trees

\begin{tabular}{|c|c|c|c|c|c|c|c|c|c|}
\hline $\begin{array}{l}\text { SI. } \\
\text { No. }\end{array}$ & Botanical Name & $\begin{array}{l}\text { Parts } \\
\text { Used }\end{array}$ & $\begin{array}{c}\text { Beverag } \\
\text { es and } \\
\text { drinks }\end{array}$ & $\begin{array}{l}\text { Fibres } \\
\& \text { floss }\end{array}$ & $\begin{array}{l}\text { Gum/ } \\
\text { Resin }\end{array}$ & Perfume & Oil & Fodder & $\begin{array}{l}\text { Timber } \\
\text { /wood }\end{array}$ \\
\hline 1 & Bombax malabarium DC & S,SD & - & + & - & - & + & - & - \\
\hline 2 & $\begin{array}{l}\text { Azadirachta } \\
\text { indica A. Juss }\end{array}$ & S,SD & - & - & + & - & + & - & - \\
\hline 3 & Bauhinia variegata $\mathrm{L}$. & $\mathrm{SF}$ & - & + & - & - & - & - & - \\
\hline 4 & $\begin{array}{l}\text { Dalbergia } \\
\text { sissoo D.C. }\end{array}$ & ST & - & - & - & - & - & - & + \\
\hline 5 & Dalbergia latifolia Roxb. & ST & - & - & - & - & - & - & + \\
\hline 6 & Ficus bengalensis $\mathrm{L}$ & LF & - & - & - & - & - & + & - \\
\hline 7 & Ficus religiosa $\mathrm{L}$. & LF & - & - & - & - & - & + & - \\
\hline 8 & Ficus virens Dryander & LF & - & - & - & - & - & + & - \\
\hline 9 & Jacaranda mimosifolia & ST & - & - & - & - & - & - & + \\
\hline 10 & Kigelia africana (Lans). Benth. & $\begin{array}{l}\text { FR, } \\
\text { SD, } \\
\text { LF }\end{array}$ & + & - & - & - & - & + & - \\
\hline 11 & Mimusopa elengi $\mathrm{L}$ & FL & - & - & - & + & + & - & - \\
\hline 12 & Pongamia pinnata (L) Pierre. & $\begin{array}{l}\text { LF, } \\
\text { SD, } \\
\text { BA }\end{array}$ & - & + & - & - & + & + & - \\
\hline 13 & Tabebuia sp. & ST & - & - & - & - & - & - & + \\
\hline
\end{tabular}

Abbreviations: $\mathrm{LF}=$ leaf, $\mathrm{ST}=$ Stem, $\mathrm{SD}=\mathrm{Seed}, \mathrm{FR}=$ Fruit, $\mathrm{FL}=$ Flower, $\mathrm{BA}=$ Bark

\section{DISCUSSION}

Morphological characters are used for identification because it is a basic method since nineteenth century and easily observable. For the study of morphological characters one need not to have sophisticated laboratory arrangements, a hand lens or dissecting microscope or light microscope is enough to study these characters.

Trees are important woody plants of our ecosystem. Woody trees are mostly, used for timber purposes but the present work describes the utility of trees with respect to their importance in restoring, reclaiming and rejuvenating denuded and disturbed soils, their ecological, eco-development and environmental use and their educational and recreational value in gardening, landscaping and aesthetic purposes. In addition the importance of trees is discussed with reference to their value as a source of different sustenance like beverages, medicines, essential oils, fatty oils, fodder, fuel, fiber, tannin, gums, resins and cork.

Present study defines the total number of transplanted trees and their morphological character and their economic importance to wild life. Hence, this research provides the basic first line information about the successful aforestation which can be used in its further extension.

Morphology of the plant described with out any specific instrument, therefore this has remain a long lasting method of plant identification. Various flora were helpful in the identification of plant.Thirteen transplanted species are described on the basis of their leaves dissimalarities, because plants were only 4 years old. Morphological characters are a part of descriptive taxonomy which developed in the nineteenth century.This was mainly concerned with the observation of similarities and differences in the morphological characters of plants. This began with the works of Tournefort,de Jusseiu and 
PRAKASH: STUDY OF MORPHOLOGICAL CHARACTERS OF TRANSPLANTED TREES WITH...

Linnaeus. In $20^{\text {th }}$ century, primary importance was given to morphological distinctness (Saxena \& Saxena, 2012).

\section{Economic Importance of Transplanted Trees}

Forest trees occupy central position in nature. They restore ecological balance of all ecosystems and maintain biological diversity. Forests have since long been looked upon as revenue generation sector. There is a need for good planning and execution of our rich, diverse forest resource which is scarce and precious.In this aspect ,the Safari plays a vital role in attaining ecological security.Floristic component is the key element of ecosystem services that actually meets the livelihood needs both for the human beings as well as other animals of Safari. (Singh et. al, 2016). Tradionally, trees are being used for the inter dependent benefits of 6 Fs i.e food, fruit, fodder, fuel, fertilizer and fibre. The multivarious benefits and services generated from tree-based system are recognized as a tool to improve the livelihood status of forest dependent people. (Chavan et al., 2015). Trees are mostly used for timber purposes, but in terms of Fisher forest and lion Safari it is also used in restoring, reclaiming and rejuvenating denuded and disturbed soils, their ecological, ecodevelopmental and environmental use and their educational and recreational value in gardening, landscaping and bioaesthitic planning. Seth (2002) given the logical meaning of "TREES"

$\mathrm{T}=$ Timber, $\mathrm{R}=$ Restoration, reclamation and rejuvenation of denuded soils, $\mathrm{E}=$ Ecological, ecodevelopmental and environmental use. E=Educational and recreational value in gardening, landscaping, biaesthetic planning. $\mathrm{S}=$ Source of sustenance i.e.food, fuel, fodder, fertilizer, fiber, medicine, tannin, dyes, oils etc.
Woods obtained from Dalbergia sissoo are used for construction and other miscellaneous purposes like agricultural implements, boat and ship building,carts and carriages, carving and turnery, cooperage (barrel making), electric poles, engraving and printing blocks, furniture and cabinet work, match and match boxes, pencil and pen holders, picture framing, railway carriage and wagon building, rifle parts, shoe heels and boot lasts, shuttle, sports goods, tea chests, toys etc. Anonymous (1970-72, 1983) and Trotter (1940, 1944).

In wild life both native and ornamental trees are present.They directly feed and provide shelter to house the majority of world's creatures and animals like insects, birds, small mammals and reptiles, which are their basic need in order to live. Thus they play a major role as one of the important components of natural and human made biodiversity. The whole forest management program is useful toprovide stability to the environment by restoring the ecological balance (Maithaniet et al.,, 1991).

Ornamental flowering trees such as Bauhinia variegata (Seth, 2003) Jacaranda mimosaefolia, Pongamia, Bombax malabaricum (Cowen, 1950; Randhawa, 19651983) are suitable for Safari.Ornamental trees with beautiful foliage called "Ornamental foliage trees Kigella sp. was recommended by Randhawa (1961), evergreen trees provide a structure for the Safari during winter months, without them garden will look bleak and dull. When the foliage of most herbaceous perennials disappears, leaving bare stems and branches. Many evergreen trees combine beauty with fragrance.Some trees that are commonly cultivated for scent and fragrance are Mimusops elengi (Randhawa,1961).

Table 5: Economic Value of Transplanted Tree

\begin{tabular}{|c|c|c|c|c|c|c|}
\hline $\begin{array}{c}\text { Sl. } \\
\text { No. }\end{array}$ & Genus \& species & $\begin{array}{c}\text { Commo } \\
\mathrm{n} \text { name }\end{array}$ & family & Part used & Product & References \\
\hline 1. & Azadirachta indica & Neem & meliaceae & Flowers & $\begin{array}{c}\text { Glucose, sucrose used in } \\
\text { honey formation }\end{array}$ & Randhawa (1965-1983) \\
\hline 2. & Dalbergia sissoo & Shisham & fabaceae & Flowers & $\begin{array}{c}\text { Glucose.sucrose used in } \\
\text { honey formation }\end{array}$ & Randhawa (1965-1983) \\
\hline 3. & Mimusops elengi & elengi & Sapotaceae & Flowers & Oil used in perfume & Seth(2002) \\
\hline 4. & Azadirachta indica & Neem & Meliaceae & Seed & Oil used as antiseptic & Seth(2002) \\
\hline 5. & Pongamia pinnata & Pongam & Fabaceae & Seed & $\begin{array}{c}\text { Oil used in soap making, } \\
\text { illuminant and } \\
\text { skindiseases. }\end{array}$ & Seth(2002) \\
\hline 6. & Bauhinia variegate & Kachnar & Caesalpinae & Leaf & fodder & Singh (1982), Anonymous \\
\hline
\end{tabular}


PRAKASH: STUDY OF MORPHOLOGICAL CHARACTERS OF TRANSPLANTED TREES WITH...

\begin{tabular}{|c|c|c|c|c|c|c|}
\hline & & & & & & (1983) \\
\hline 7. & Fi cus religiosa & Pipal & Moraceae & Leaf & fodder & $\begin{array}{c}\text { Singh (1982), Anonymous } \\
(1983)\end{array}$ \\
\hline 8. & Azadirachta indica & Neem & Meliaceae & Wood & Fuel & $\begin{array}{l}\text { Singhal and Khanna } \\
\text { (1991) }\end{array}$ \\
\hline 9. & Dalbergia sissoo & Shisham & Fabaceae & wood & fuel & $\begin{array}{c}\text { Singhal and } \\
\text { Khanna,(1991) }\end{array}$ \\
\hline 10. & Ficus bengalensis & Bargad & Moraceae & Bark & fibre & Seth(2003) \\
\hline 11. & Ficus religiosa & Pipal & Moraceae & Bark & fibre & $\operatorname{Seth}(2003)$ \\
\hline 12. & Bombax malabaricum & Semal & $\begin{array}{c}\text { Bombacace } \\
\text { ae }\end{array}$ & Fruits & fibre & $\operatorname{Seth}(2003)$ \\
\hline 13. & Azadirachta indica & neem & Meliaceae & Trunk & Gum & Seth(2003) \\
\hline 14. & Ficus religiosa & Pipal & Moraceae & Twig & $\begin{array}{c}\text { Resin obtained from lac } \\
\text { insect }\end{array}$ & $\operatorname{Seth}(2003)$ \\
\hline
\end{tabular}

The present investigation was conducted with the objectives of Morpho-physiological study of transplanted tree in Fisher forest and Lion Safari in U.P. It is expected that the study will provide useful information about the morphological study of transplanted trees which are suitably employed in forest management. It is easiest and authentic method of identification used from ancient times. Leaves, flowers and fruits play major role in identification of plants. Leaves are important part of the tree which mainly participated in physiological process of plants and modified into floral parts. Leaves are also main characteristic feature of tree for their identification.

Naturally forests are sufficient for greenery and vegetation but Fisher forest is a man made forest. Due to overgrazing and cutting of trees, it is required to maintain best forest ecosystem by transplantation of trees and development of Safari. Economically rich forest ecosystem is the backbone of ant nation. Therefore study of economic value of trees is the most important part in forest ecosystem.

Acclimatization of transplanted tree is also an important part of afforestation of trees which may be suitably employed to improve planting practices and to boost up the rich economic resources.

Thus the findings of the present investigation demonstrate that Morphological methods are suitable for identification of plants. Their economic value is limited to the fodder, timber and some medicinal use.

\section{ACKNOWLEDGEMENT}

I heartly acknowledged University Grants Commission, New Delhi for giving financial support to this research work. I am also grateful to Dr. Anuj Saxena for his valuable suggestions to improve the manuscript significantly.

\section{REFERENCES}

Anonymous, 1970-72, 1983. Indian forest utilization .Comp.and ed.Forest Research Institute and college, Dehra Dun. 2 vols. Manager of Publications, Delhi.

Anonymous, 1983. Forests of Himachal Pradesh .Department of forests, Farming and Conservation, Himachal Pradesh, Kunihar, India.

Chavan S.B., Keerthika A., Dhyani S.K., Handa A.K., Ram Newaj and Rajarajan K., 2015. National Agroforestry Policy in India: a low hanging fruit. Curr. Sci., 108:1826-1834.

Edward F. Gilman and Dennis G. Watson, 1994. Pongamia pinnata Pongam Fact sheet ST-498.

Garg A., Singh V.K. and Singh R.K., 2014. Economically valuable wild plant resources of Nawabganj Bird Sanctuary, Uttar Pradesh. J. Non-Timber For Proc., 21(2):99-104.

Hultine K.R. and Marshall J.D., 2000. Altitiude trends in conifer leaf morphology and stable carbon isotope composition. Oecologia, 123:32-40. 


\section{PRAKASH: STUDY OF MORPHOLOGICAL CHARACTERS OF TRANSPLANTED TREES WITH...}

Joshi D.P., 1953. Working plan for Fisher forest and Sarangpur Tora Blocks of southern Doab division 1948-49 to 1962-62. P 84-23 Allahbad Superintendent,p rinting and stationary, Uttar Pradesh, India.

Li F.L. and Bao W.K., 2014. Elevahonal trends in leaf size of Camphylotropis polyantha in the arid Min jiang River Valley, S W China. J. Arid Environ., 108:19.

Lowry O.H., Roseborough N.J., Farr A.L. and Randall R.J., 1951. Protein measurement with Folin-Phenol reagent. J. Biol. Chem., 193:265-275.

Lusk C.H. and Warton D.I., 2007. Global meta-analysis shows that relationships of leaf mass per area with species shade tolerance depend on leaf habit and ontogeny. New Phytol, 176:764-774.

Maitheni G.P., Bahuguna V.K., Negi J.D.S. and Nautiyal S., 1991. Handbook of some important Himalyan shrubs, ICFRE-1, F.R.I. Dehra Dun, India.

Marcos melocorrea, veridiana, vizoniscudellur and maria Graciman Pacheco de Araiya, 2015. Comparative leaf morphological analysis of 20 species of chrysobalanceae: Acta Amaz., 45(1).

Mathur R.C. and Chauhan S.V.S., 1988. Systematic Botany (Angiosperm) Agra Book Store pg 37.

Mishra D.N., 1988. Uttar Pradesh mai Vrishropan ki Margdarshika. Publ. Society for promotion of wastelands development, New Delhi Pg. 75-149.

Nagendra H., Pareeth S. and Ghate R., 2006. People within parks: Forest villages, land cover change and landscape fragmentation in then Tadoba -Andhari Tiger Reserve, India, Appl. Geogr., 26:96-112.

Pandey B.P., 1985. A text book of Botany Angiosperms- p171-172. Sultan Chand\&publication 1td, New Delhi.

Prakash A. and Saxena A., 2017. Study of plant diversity of Fisher forest and Lion safari, Etawah Uttar Pradesh, India Pg. 412-420. Publ. Global Academic Publ. Kalyanpur, Lucknow.

Randhawa M.S., 1961. Beautiful trees and gardens .Indian Council of Agricultural Research, New Delhi.
Randhawa, 1965-1983. Flowering trees. National Book trust, New Delhi.

Seth M.K., 2003. Trees and their economic importance. The Botanical Review, 69(4):321-376.

Saxena and Saxena. Plant Taxonomy, Publ. Pragati Prakashan Meerut Eight Edition 2012, Pg. No. 4.

Saxena N.B. and Saxena S., 2012. Plant taxonomy. Pragati Prakashan, Meerut.

Seth, 2002. The logical meaning of Shrubs and treess. The Botanica (communicated).

Shukla B.K., 2012. A report on the floristic diversity of Chambal Wildlife Sanctaury, Uttar Pradesh, Botanical Survey of India, Kolkata.

Shukla B.K. and Singh A.N., 2016. Flora of Uttarakhand Vol.1 pg 405 Botanical Survey of India, Kolkata.

Shukla P. and Mishra S.P., 1992. An Introduction to taxonomy of Angiosperm. Vivek Publishing house Pvt. Ltd. Pg. 137.

Singh K.K., 1977. Flora of Dudhwa National Park (Kheri district, U.P.) Bishen Singh Mahendra Pal Singh, Dehradun 516 pp.

Singh K.P., Khanna K.K. and Sinha G.P., 2016. Flora of Uttar Pradesh vol.I, Publ. Botanical Survey of India, Kolkata (Preface).

Singh R.V., 1982. Fodder trees of India. Oxford and IBH Publishing Co. New Delhi.

Singhal R.M. and Khanna P., 1991. Multipurpose Trees and Shrubs ICFRE -16, F.R.I, Dehradun, India.

Trotter H, 1940-44. (Reprinted 1958-1960). The common commercial timbers of India and their uses. Manager of Publications, Delhi.

Troup R.S., 1932). Exotic, forest trees in the British Empire (e-book) Oxford, At the Clarendon Press Pg 8-9.

https://en.m.wikipedia.org

www.scielo.br $>$ scieb.

http://sites.google.com>bignoniaceae

https://www.holidify.com 